\title{
VR 039-16 Grape Rootstock
}

\author{
M. Andrew Walker', Lloyd A. Lider, Austin C. Goheen', and \\ Harold P. Olmo \\ Department of Viticulture and Enology, University of California, Davis, \\ CA 95616
}

Additional index words. Vitis, grape breeding, disease resistance, fanleaf degeneration

Fanleaf degeneration is one of the most serious grapevine diseases. Caused by grapevine fanleaf virus (GFLV), it is compounded by the feeding damage of Xiphinema index Thorne and Allen, the nematode vector. The disease progresses rapidly, and yields of infected vines eventually decrease up to $80 \%$ (Martelli and Savino, 1988). Efforts to control the vector with nematicides were not completely successful, as explained in a review by Raski et al. (1983). These and similar results led to the initiation, more than 20 years ago, of a breeding program at the Univ. of California, Davis, to develop a grapevine rootstock resistant to fanleaf degeneration. This rootstock breeding program continues with the goal of combining sources of resistance to GFLV with sources of resistance to $X$. index. We report on VR 039-16, an interim release from that program.

\section{Origin}

VR 039-16 was selected from the cross Vitis vinifera L. cv. Almeria $\times$ V. rotundifolia Michx. Male No. 1 made in 1948 by H.P. Olmo at the Univ. of California, Davis. This and other $V$. vinifera $\times V$. rotundifolia (VR) hybrids were initially used to study cytogenetic relationships between $V$. vinifera and $V$. rotundifolia (Patel and Olmo, 1955), and later were screened for use as phylloxera (Daktulosphaira vitifoliae Fitch)-resistant rootstocks (Davidis and Olmo, 1964). VR hybrids were included in a 1979 field screening for rootstocks resistant to fanleaf degeneration. VR 039-16 excelled in this trial (Walker et al., 1989) and was patented (Lider et al., 1988) and released.

\section{Description}

VR 039-16 is a sterile $F_{1}$ hybrid. The flowers appear staminate with rudimentary pis-

Received for publication 28 Dec. 1990. This work was supported in part with funding from the Wine Institute and the American Vineyard Foundation. The current collaboration with J.A. Wolpert is gratefully acknowledged. The cost of publishing this paper was defrayed in part by the payment of page charges. Under postal regulations, this paper therefore must be hereby marked advertisement solely to indicate this fact.

'To whom reprint requests should be addressed. ${ }^{2}$ Retired, U.S. Dept. of Agriculture, Dept. of Plant Pathology, Univ. of California, Davis. tils; however, pollen and ovules are nonfunctional. The mature leaves have three to five lobes, dentate margins with teeth of various sizes, and a narrow to closed U-shaped petiolar sinus (Fig. 1). They are glossy yellow-green and glabrous, with the exception of tufted hairs at the intersection of the main veins on the lower surface. Shoot tips are slightly curved, covered with downy white tomentum, and have red margins. As the young leaves develop, they become almost glabrous, with few tufted hairs on the upper surface. Tendrils are long, bifid, and discontinuous. Mature wood is tan with persistant bark and prominent lenticels. The nodes have a diaphragm.

\section{Performance data}

VR 039-16 has been grafted with $V$. vinifera 'Cabernet Sauvignon', 'Carignane', and 'Chenin blanc', and no signs of graft incompatibility have been detected during 11 years.
Scions grafted on VR 039-16 are vigorous, have high yields, and display field resistance to the effects of fanleaf degeneration.

VR 039-16 has performed well in a site contaminated with GFLV/X. index complex and phylloxera in the Napa Valley, Calif., since 1979 (Walker et al., 1989). We compared the performance of 'Cabernet Sauvignon' grafted on VR 039-16 and three susceptible rootstocks at this site (Table 1). 'Cabernet Sauvignon' on VR 039-16 remained free of fanleaf degeneration until 1987, as determined by enzyme-linked immunosorbent assay (ELISA) (Clark and Adams, 1977). Yields of the one infected replicate of ' $\mathrm{Ca}$ bernet Sauvignon' on VR 039-16 were suppressed in 1988 and 1989 (4.7 and $8.0 \mathrm{~kg}$ / vine vs. an average for all four replicates of 8.6 and $11.4 \mathrm{~kg} / \mathrm{vine}$ ), but not as drastically as the yields of 'Cabernet Sauvignon' on susceptible stocks. However, vine replication was not adequate for statistically significant conclusions. 'Cabernet Sauvignon' on susceptible rootstocks expressed severe symptoms of fanleaf degeneration, as evidenced by reduced yield, and was rapidly infected by GFLV. Recently planted trials with VR 039-16 will establish the degree of resistance that VR 039-16 possesses against fanleaf.

Davidis and Olmo (1964) reported that VR 039-16 and some other VR hybrids were resistant to phylloxera. Unpublished data from potted vines in the greenhouse (M.A.W.,

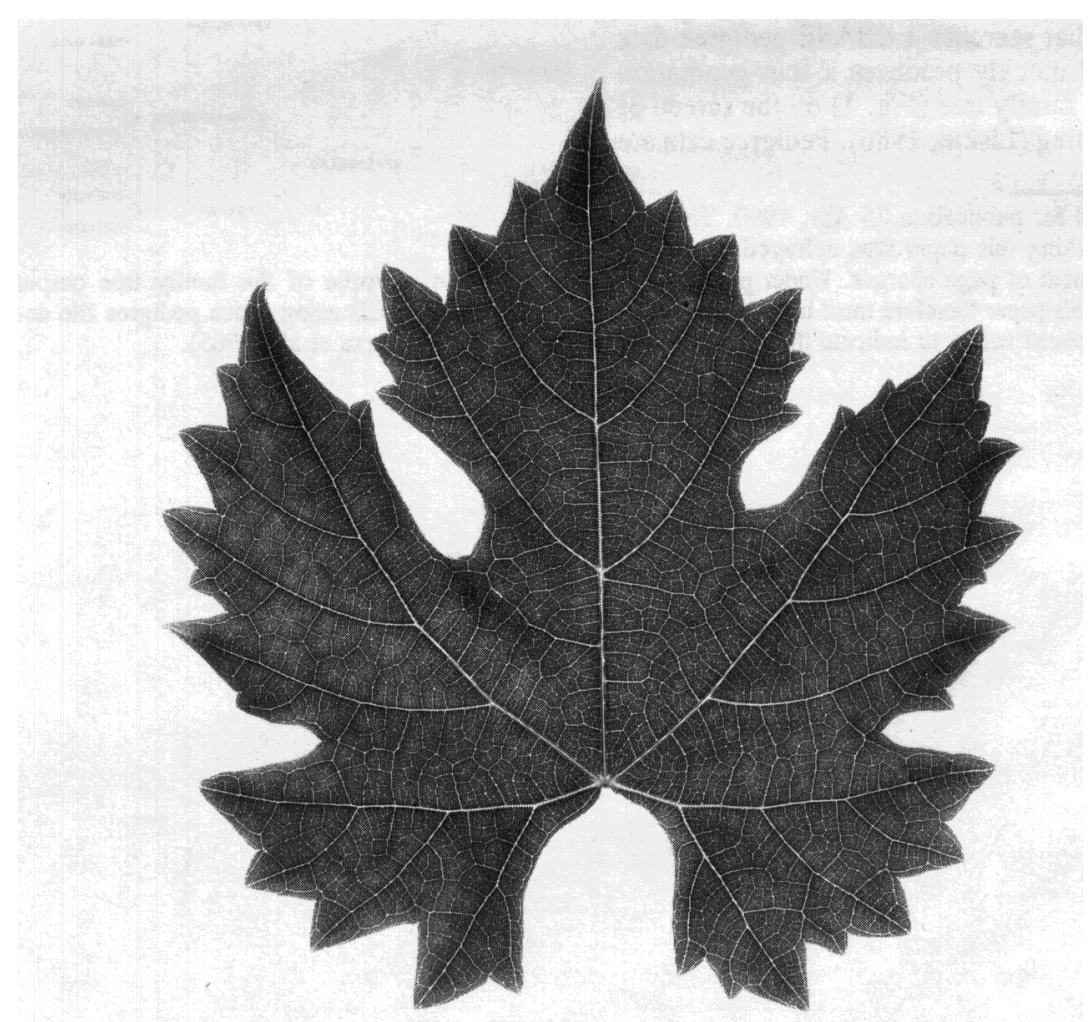

Fig. 1. Mature leaf of grapevine (Vitis) rootstock VR 039-16. 
Table 1. Fruit yields and results for ELISA tests for 'Cabernet Sauvignon' scions on four rootstocks planted in a site in the Napa Valley, Calif., infected with fanleaf degeneration. ${ }^{2}$

\begin{tabular}{lccl}
\hline \hline $\begin{array}{l}\text { Year and } \\
\text { rootstock }\end{array}$ & $\begin{array}{c}\text { Yield/vine } \\
(\mathrm{kg})\end{array}$ & $\begin{array}{c}\text { Pruning wt } \\
(\mathrm{kg})\end{array}$ & \multicolumn{1}{c}{ ELISA results } \\
\hline 1984 & & & \\
VR 039-16 & 10.4 & 4.7 & All vines virus free \\
AXR\#1 & 8.7 & 2.6 & $1-, 1+, 2++$ vines \\
Harmony & 5.0 & 2.9 & $1-, 4++$ vines \\
St. George & 3.4 & 1.4 & All vines ++ \\
1985 & & & \\
VR 039-16 & 12.2 & 4.3 & All vines virus free \\
AXR\#1 & 6.7 & 3.0 & $2+, 2++$ vines \\
Harmony & 3.7 & 2.1 & $1-, 4++$ vines \\
St. George & 2.2 & 1.4 & All vines ++ \\
1986 & & & \\
VR 039-16 & 16.0 & 6.2 & All vines virus free \\
AXR\#1 & 6.7 & 3.0 & $1+, 3++$ vines \\
Harmony & 4.3 & 3.0 & All vines ++ \\
St. George & 3.2 & 2.3 & All vines ++ \\
1987 & & & \\
VR 039-16 & 9.4 & 6.7 & All vines virus free \\
AXR\#1 & 7.1 & 2.5 & All vines ++ \\
Harmony & 3.6 & 2.5 & All vines ++ \\
St. George & 2.7 & 2.4 & All vines ++ \\
1988 & & & $1+, 3-$ vines \\
VR 039-16 & 8.6 & Not taken & All vines ++ \\
AXR\#1 & 1.8 & Not taken & All vines ++ \\
Harmony & 1.3 & Not taken & All vines ++ \\
St. George & 1.1 & Not taken & $1+, 3-$ vines \\
1989 & & & All vines ++ \\
VR 039-16 & 11.4 & 5.8 & All vincs ++ \\
AXR\#1 & 2.2 & 2.3 & All vines ++ \\
Harmony & 1.3 & 2.5 & \\
St. George & 1.6 & & \\
\hline & & & \\
Va ges & & & \\
\hline
\end{tabular}

${ }^{2}$ Values given are means of three to five single-vine replicates.

'ELISA values - , negative; +, moderate virus level; + + , high virus level.

unpublished data) and from laboratory studies with excised roots (Granett et al., 1987) confirm that phylloxera do not feed upon or colonize VR 039-16. Granett et al. (1987) also determined that VR 039-16 had excellent field resistance to phylloxera. Studies by McKenry and Kretsch (1989) state that VR 039-16 has a high degree of resistance to $X$. index and phylloxera; however, it was less resistant or susceptible to other plant parasitic nematodes.

Vitis rotundifolia roots very poorly from dormant cuttings (Goode et al., 1982), and dormant cuttings of VR hybrids are more difficult to root than standard grape rootstocks. However, bench-grafting and propagation success approached $95 \%$ when indole3-butyric acid (100 ppm soak for $24 \mathrm{~h}$ ) and conditions conducive to callus formation (14 days in the dark at $25 \mathrm{C}$ and $70 \%$ relative humidity) were used to prepare dormant cuttings before grafting (L.A.L., unpublished data.

Uses

There is urgent need in the viticultural in- dustry for a rootstock resistant to fanleaf degeneration. VR 039-16 was released as an interim solution to fanleaf degeneration resistance from an ongoing grape rootstock breeding program. It is recommended for use only on sites with the GFLV/X. index complex and is currently the best solution to this disease. VR 039-16 is patented (Lider et al., 1988) and widely available from California grape nurseries.

\section{Literature Cited}

Clark, M.F. and A.N. Adams. 1977. Characteristics of the microplate method of enzyme-linked immunosorbent assay for the detection of plant viruses. J. Gen. Virol. 34:475-483.

Davidis, U.X. and H.P. Olmo. 1964. The Vitis vinifera $\times V$. rotundifolia hybrids as phylloxera resistant rootstocks. Vitis 4:129-143.

Goode, D.K., G.W. Krewer, R.P. Lane, J.W. Daniell, and G.A. Couvillon. 1982. Rooting studies of dormant muscadine grape cuttings. HortScience 17:644-645.

Granett, J., A.C. Goheen, L.A. Lider, and J.J. White. 1987. Evaluation of grape rootstocks for resistance to type A and type B grape phylloxera. Amer. J. Enol. Viticult. 38:298-300.

Lider, L.A., H.P. Olmo, and A.C. Goheen (inventors). 1988. The Regents of the University of California, assignee. Hybrid grapevine rootstock. U.S. plant patent 6166. 3 May 1988.3p. Int. $\mathrm{Cl}^{4}$.

Martelli, G.P. and V. Savino. 1988. Fanleaf degeneration, p. 48-49. In: R.C. Pearson and A.C. Goheen (eds.). Compendium of grape diseases. APS Press, St. Paul.

McKenry, M. and J. Kretsch. 1989. Nematode/ rootstock profile. Proc. San Joaquin Valley Grape Day, Univ. of California, Kearney Agricultural Center, Parlier, 9 Aug. 1989.

Patel, G.I. and H.P. Olmo. 1955. Cytogenetics of Vitis: I. The hybrid $V$. vinifera $\times V$. rotundifolia. Amer. J. Bot. 42:141-159.

Raski, D.J., A.C. Goheen, L.A. Lider, and C.P. Meredith. 1983. Strategies against grapevine fanleaf virus and its nematode vector. Plant Dis. 67:335-339.

Walker, M.A., J.A. Wolpert, E.P. Vilas, A.C. Goheen, and L.A. Lider. 1989. Resistant rootstocks may control fanleaf degeneration of grapevine. Calif. Agr. 43(2):13-14. 